\title{
Apple Pomace as a Functional and Healthy Ingredient in Food Products: A Review
}

\author{
Fengzhi Lyu ${ }^{1}$, Selma F. Luiz ${ }^{2}$, Denise Rosane Perdomo Azeredo ${ }^{2}$, Adriano G. Cruz ${ }^{2}$, \\ Said Ajlouni ${ }^{1}$ and Chaminda Senaka Ranadheera ${ }^{1, *}$ (i)
}

1 School of Agriculture \& Food, Faculty of Veterinary and Agricultural Sciences, The University of Melbourne, Parkville, VIC 3010, Australia; lyufengzhi@gmail.com (F.L.); said@unimelb.edu.au (S.A.)

2 Department of Food, Federal Institute of Rio de Janeiro (IFRJ), Food Department, CEP 20270-021 Rio de Janeiro, Brazil; Selmafranciscoluiz@gmail.com (S.F.L.); denise.perdomo@ifrj.edu.br (D.R.P.A.); adriano.cruz@ifrj.edu.br (A.G.C.)

* Correspondence: senaka.ranadheera@unimelb.edu.au; Tel.: +61-3-9035-5836

Received: 5 February 2020; Accepted: 4 March 2020; Published: 9 March 2020

check for updates

\begin{abstract}
Apple pomace is a major by-product obtained during apple juice processing. Several million metric tons of apple pomace are estimated to be generated worldwide every year. However, the recovery rate of this by-product is low. Pomace is commonly disposed and thrown away as a waste, which results in environmental problems and even public health hazards. As a by-product of the apple juice processing industries, pomace contains plenty of different varieties of nutritionally important compounds, such as carbohydrates, phenolic compounds, dietary fiber and minerals. These important compounds can be recovered from apple pomace, or there is even a possibility of using apple pomace in the food systems directly or after minimal processing. Therefore, apple pomace can be utilized in food products to improve their health benefits and commercial values. This review focuses on the current food applications and influence of apple pomace on the characteristics of various food products.
\end{abstract}

Keywords: apple pomace; food processing wastes; bioactives; functional ingredients

\section{Introduction}

Apple (Malus domestica Borkh.) is one of the earliest fruit known to humans and is widely cultivated in temperate regions [1]. Following oranges, bananas and grapes, apples are the fourth most consumed fruit crop in the world [2]. It has been reported that the global per capita consumption of apples exceeded $9 \mathrm{~kg}$ in 2013 [1] and has been further increased over time. According to the latest report by FAO [3], the annual world production of apples has increased by $48 \%$ over the last two decades and reached 83.1 million metric tons in 2017. As the original center for apples, Asia accounted for $65.4 \%$ of the world production, with China producing 41.4 million metric tons. Other major producers include the US, Turkey and Poland, representing $6.2 \%, 3.6 \%$ and $2.9 \%$ of the total worldwide production, respectively.

Although the global apple production continues to grow, the share of its consumption is relatively stable. Apples used for fresh consumption account for $70 \%-75 \%$ while the rest $(25 \%-30 \%)$ of world total production is processed to various value-added products including juice, wine, jams and dried product $[4,5]$. However, apple juice is still the most demanded apple product, accounting for $65 \%$ of the total amount of processed apple [6]. Generally, nearly $75 \%$ of apple fresh weight is supposed to be extracted as juice during juice production, and the left-over is collected as a food waste, the so-called pomace [7]. 
Considering the worldwide mass production of juice, a total of several million metric tons of the pomace is estimated to be generated every year [6]. The approximate quantity of apple pomace production in certain countries is given in Table 1, which is expected to have a further increase in future. However, the recovery rate of this by-product is quite low. In India, for example, only approximately $1 \%$ of the apple pomace can be utilized as animal feed or dry product [5]. The most common disposal method for this by-product is to discard it directly to the soil in a landfill, which is suggested to cause serious environmental problems associated with pollution $[4,5,8,9]$. This is mainly due to the rich water content $(>70 \%)$ and the high biodegradable organic load (chemical and biochemical oxygen demand) of apple pomace. The former leads to a great susceptibility to microbial decomposition, resulting in unpredictable fermentation while the latter contributes to environmental pollution and even public health hazards [4]. Consequently, researchers suggested that professional waste disposal should be applied in apple juice plants to reduce environmental problems, which may require additional economic investments [10]. Therefore, it is necessary to explore safe and efficient treatments of apple pomace and its effective utilization in the food and nutraceutical industries. Considering the large volume of this by-product generated from production and processing of juice, the commercial applications of pomace can create great economic impact [5]. Some success has been achieved in transforming a variety of agricultural and food processing waste into commercially viable products including bio-fuels, nutrients and multifunctional ingredients [11]. Similarly, in recent years, various applications of apple pomace have been considered in order to raise its recovery rate.

Table 1. Quantities of apple pomace production in certain countries.

\begin{tabular}{ccc}
\hline Country & $\begin{array}{c}\text { Quantity } \\
\text { (Metric Tons) }\end{array}$ & Ref. \\
\hline Brazil & 800,000 & {$[7]$} \\
China & $1,000,000$ & {$[12]$} \\
Germany & 250,000 & {$[13]$} \\
India & $1,000,000$ & {$[5]$} \\
Iran & 97,000 & {$[14]$} \\
Japan & 160,000 & {$[15]$} \\
United States & 27,000 & {$[16]$} \\
\hline
\end{tabular}

Currently, apple pomace is used as a functional ingredient in food products due to its high nutrient content [17]. Most of the previous reviews on utilization of apple pomace have been focused on the recovery of functional bioactive compounds from apple pomace and applications of these compounds in various nutraceutical products. However, there is an increasing interest in utilizing apple pomace directly or with minimal processing in food products. Therefore, this review mainly summarizes the current food applications of apple pomace as direct ingredient or after minimum processing in food manufacturing with special reference to the influence of apple pomace on the characteristics of various food products. Utilization of apple pomace as a substrate to produce food and beverages is also briefly discussed.

\section{Composition and Nutritional Value of Apple Pomace}

Apple pomace is a heterogeneous mixture consisting mainly of skin and flesh (95\%), with a tiny proportion of seeds $(2 \%-4 \%)$ and stems $(1 \%)[4,18]$. Its physical-chemical composition has been determined by numerous studies (Table 2 ) and it shows a variation according to the variety and processing type used in apple juice production [7]. 
Table 2. Different physical-chemical compositions of apple pomace.

\begin{tabular}{|c|c|c|c|c|}
\hline Composition (\%) ${ }^{1}$ & $\begin{array}{l}\text { Wang et al. } \\
\text { (2019) [19] }\end{array}$ & $\begin{array}{l}\text { Jin et al. } \\
(2002)[20]\end{array}$ & $\begin{array}{c}\text { Jannati et al. } \\
\text { (2018) [21] }\end{array}$ & $\begin{array}{l}\text { Ktenioudaki et al. } \\
\text { (2013) [22] }\end{array}$ \\
\hline Moisture & 4.4 & 5.8 & 10.5 & 7.1 \\
\hline Protein & 3.8 & 4.7 & 1.2 & 2.4 \\
\hline Lipids & 3.8 & 4.2 & 0.6 & 2.7 \\
\hline Total Dietary Fiber & 26.5 & $\mathrm{NR}^{2}$ & 14.5 & 42.5 \\
\hline Ash & 1.8 & 1.5 & 2.5 & 1.7 \\
\hline Carbohydrates & 45.1 & 83.8 & $\mathrm{NR}^{2}$ & $\mathrm{NR}^{2}$ \\
\hline
\end{tabular}

Despite the differences in content, the variety of nutrients in apple pomace is rich. It is a good source of phytochemicals and contain significant amounts of carbohydrate as well as small amounts of proteins, vitamins and minerals [4]. The apple pomace carbohydrates consist mainly of insoluble sugars including cellulose (127.9 g/ $\mathrm{kg}$ DW), hemicellulose (7.2 to $43.6 \mathrm{~g} / \mathrm{kg} \mathrm{DW})$ and lignin (15.3 to 23.5 $\mathrm{g} / \mathrm{kg} \mathrm{DW})$, with simple sugars such as glucose (22.7\%), fructose (23.6\%) and galactose (6\% to $15 \%)$ [23]. In addition to carbohydrates, some minerals were also determined in apple pomace, such as $\mathrm{P}(0.07 \%$ to $0.076 \%$ ), $\mathrm{Ca}(0.06 \%$ to $0.1 \%), \mathrm{Mg}(0.02 \%$ to $0.36 \%$ ) and $\mathrm{Fe}$ (31.8 to $38.3 \mathrm{mg} / \mathrm{kg}$, dry weight basis). Apple pomace is also characterized by a high proportion of polyphenols ( $31 \%$ to $51 \%$ ), especially cinnamate esters, dihydrochalcones and flavonols [24]. Furthermore, it has been proven that apple pomace has a broad content of natural antioxidants such as quercetin glycosides, phloridzin and other phenolic constituents that have strong antioxidant activity $[25,26]$. Therefore, apple pomace is of great nutritional value, providing health benefits. Several studies indicated that apple pomace not only helps in the prevention of constipation and hypertension but also can scavenge certain harmful substances in the human body such as free radicals [4]. The existence of these value-added compounds also indicates the potential of apple pomace being utilized as an ingredient in the food industry.

\section{Use of Apple Pomace as a Functional Ingredient in Food Products}

Due to the high content of dietary fiber, phenolic compounds and other nutrients, apple pomace is regarded as a good functional ingredient to be incorporated in various food products. However, the addition of apple pomace is reported to cause a decline in certain quality parameters of food products. Therefore, the addition level of pomace as a functional ingredient is relatively low [17], and these amounts should be carefully monitored.

\subsection{Bakery Products}

Various bakery products including bread, cakes and cookies have been consumed by humans for hundreds of years and are widely accepted [17]. The application of apple pomace in bakery foods is considered to improve the dietary fiber content and health benefits $[27,28]$. However, pomace addition results in a decrease in quality and sensory properties of baked products in the majority of cases [29-31]. Therefore, efforts have been undertaken to evaluate the effects of apple pomace on each individual bakery product and optimize the utilization level to incorporate.

\subsubsection{Bread}

Efforts have been made to apply apple pomace as a supplement of dietary fiber in bread making over the last few decades $[17,27,31,32]$. A study by Masoodi and Chauhan examined the application of $2 \%, 5 \%, 8 \%$ and $11 \%$ apple pomace in wheat bread making [27]. Their results showed that with the pomace level increasing from $0 \%$ to $11 \%$, the loaf weight increased by $3.1 \%$ in the neutralized dough (dough with acidity-neutralized apple pomace) and by $7 \%$ in the un-neutralized one. The loaf volume was observed to be reduced by $26.6 \%$ and $42.8 \%$ in neutralized and un-neutralized doughs, respectively. The crust color and bread hardness were also found to increase with the pomace level. Moreover, although the overall score of the organoleptic evaluation was gradually decreased, the bread 
made with $5 \%$ pomace was considered to be acceptable and obtained the highest scores in respect of odor and taste. Similar findings have been demonstrated in depth by Ktenioudaki et al. (2013), with a particular focus on the rheological properties of dough [22]. The incorporation of apple pomace to wheat flour was found to reduce the uniaxial extensibility while raising the biaxial extensional viscosity of dough. It led to the low volume and dense structure of the bread. Nevertheless, the opposite effect of adding apple pomace on bread hardness was described by Jannati et al. (2018). They evaluated the quality of Sangak bread (a traditional Iranian bread) that included apple pomace powder (1\% to $7 \% \mathrm{w} / \mathrm{w}$ of flour) [21]. The results indicated that adding apple pomace can reduce the hardness of bread texture and delayed its staling progress. They concluded that adding apple pomace at $3 \%$ was the most effective. In addition, the sensory analysis showed that adding less than $3 \%$ of the pomace could improve the smell, texture and overall acceptability of the bread, which is also different from the conclusion of Masoodi and Chauhan (1998) [27]. Therefore, the application of apple pomace as a functional ingredient in bread making is feasible. Future studies are required to verify the appropriate proportion of apple pomace in different types of bread.

According to Sudha et al. (2016), buns containing 15\% dehydrated apple pomace and dough conditioners increased in volume by $30 \%$ compared with no conditioner counterparts [31]. These additives included glycerol monostearate $(0.25 \%)$, sodium stearoyl lactylate $(0.25 \%)$, gluten $(2 \%)$ and $\alpha$-amylase $(1 \mathrm{mg})$. Besides volume, the firmness together with overall sensory score of the buns with conditioners and pomace were also improved.

\subsubsection{Sweet Bakery Products (Cakes, Including Scones and Muffins)}

Currently, a number of research studies have been done on the use of apple pomace in cakes and other sweet bakery products in order to enhance their flavor and nutritional values $[17,21,30,33]$. Masoodi et al. (2002) reported the application of apple pomace with different proportions $(5 \%, 10 \%$ and $15 \%$ ) in cake making [33]. They concluded that with the increase of pomace level, the cake volume reduced dramatically, while the particle size showed an opposite trend. Moreover, remarkable increases were observed in shrinkage and uniformity index after the addition of apple pomace, but there were no significant differences between $10 \%$ and $15 \%$ treatments. Similar results were reported by Sudha et al. (2007), who increased the addition level of apple pomace up to $30 \%$ in cakes [30]. The data revealed that the volume of cake with $30 \%$ pomace decreased by $37 \%$ compared with the control. As the added pomace level increased from $10 \%$ to $30 \%$, the density increased accordingly from 0.49 to $0.67 \mathrm{~g} / \mathrm{cc}$, which indicated a harder texture. However, in the organoleptic test, cakes with pomace obtained high scores in eating quality and overall acceptability, with the exception of $30 \%$ treatment which had a lower evaluation. Owing to the pleasant fruity odor, Sudha et al. (2007) also regarded apple pomace as a potential flavoring ingredient in cake products, which needs more experiments to implement at the commercial scale [30].

Moreover, apple pomace has also been reported to be used as a wheat flour substitute in muffins [28,29]. A more recent study by Sudha et al. (2016) showed that muffins with less than $20 \%$ apple pomace were not only normally symmetrical in shape but also scored highly on sensory tests for color, taste and texture [31]. However, once the replacement level exceeded $20 \%$, the evaluation of crust and crumb color showed a significant decrease because it changed from creamier yellow to brown. These results were in agreement with the findings claimed by Jung et al. (2015) [29]. However, a preference test carried by Wang and Thomas (1989) demonstrated a superior satisfaction for muffins with $50 \%$ pomace [28]. The overall preference was $79.2 \%$ while the nonfortified muffins were only $20.8 \%$. In addition to flavor improvement, the utilization of apple pomace was proven to increase the total dietary fiber (TDF), total phenolics content (TPC) and antioxidant activity [28,31]. Furthermore, Reis et al. (2014) explored the application of apple pomace in scones [34]. They found that incorporation of $20 \%$ apple pomace significantly increased the total flavonoid content (TFC), TPC and proanthocyanidins content (PAC) of scones by 4-, 3.3- and 3.1-fold, respectively. Therefore, 
apple pomace can be considered as a great functional ingredient for improving the health-promoting properties of these types of bakery foods.

\subsubsection{Brittle Bakery Products (Cookies and Crackers)}

Similar to cake doughs, cookie doughs are rich in sugars and lipids that may mask bitter taste caused by the application of apple pomace in the final products [17]. In this case, cookies have a high tolerance for the addition of apple pomace, with some studies even reporting substitution level as high as 30\% [31]. In a recent study, Lauková et al. (2016) applied hydrated apple pomace powder to partially replace wheat flour during cookie making [35]. Results showed that with the replacement level increasing from $0 \%$ to $15 \%$, the physical properties of cookies such as volume, diameter and porosity declined sharply by $23 \%, 11 \%$ and $25 \%$, respectively. Meanwhile, the fruity flavor of the cookies increased while the grain taste was reduced after the substitution. The overall satisfaction of fortified cookies was found to decrease in sensory evaluation, but the acceptance of all the treatments was above $90 \%$. Additionally, according to Kohajdová et al. (2014), adding 5\% of the apple pomace had no significant change in the sensory properties of cookies, which was consistent with the findings of Toledo et al. (2017) [36,37]. Jung et al. (2015) prepared cookies with apple pomace flour of $15 \%$ and $20 \%$ substitution level. With the incorporation of pomace, cookies were observed to be considerably darker and redder [29]. This finding is concurrent with other bakery products as well. Furthermore, all of these studies mentioned a falling tendency in firmness, which became more marked with the increase of apple pomace replacement level. However, an opposite change in the firmness of apple-pomace-fortified cookies was observed by Sudha et al. (2016), who applied up to $30 \%$ of dehydrated apple pomace in cookies [31]. In addition, a mixture of glycerol monostearate $(0.25 \%)$ and sodium stearoyl lactylate $(0.25 \%)$ was developed as an additive to alleviate the quality deterioration in cookie caused by the addition of apple pomace [31].

Notably, Alongi et al. (2019) indicated that the addition of apple pomace can reduce the glycemic index of cookies [38]. As the replacement level increased from $0 \%$ to $20 \%$, cookie glycemic index reduced from 70 to 60 . As a result, this apple-pomace-enriched product can be ranked as an intermediate glycemic index food. Moreover, a gluten-free cracker made from brown rice flour and $3 \%, 6 \%$ or $9 \%$ of apple pomace was developed by Mir et al. (2017). It was noted that the incorporation of pomace significantly increased the content of minerals such as chlorine and potassium, as well as the antioxidant activity; TDF and TPC were also increased [39]. Therefore, apple pomace can be regarded as a nutritional and functional ingredient in bakery products. Future studies are recommended to develop various types of functional baked foods with apple pomace as an ingredient.

\subsection{Extruded Food Products}

The addition of apple pomace in extruded snack products has been proven to enhance their nutritional value without causing significant negative effects on the physical properties of the snacks [40]. The current research mainly focuses on the development of optimal processing conditions, considering that in addition to the amount of apple pomace, there are a number of parameters that can affect the quality of extruded food [41,42]. Singha and Muthukumarappan (2018) developed an extruded snack based on apple pomace, defatted soy flour and corn grits by single screw extrusion [9]. With the pomace level increasing from $0 \%$ to $20 \%$, the bulk density, antioxidant capacity and TPC raised markedly. The expansion ratio was noted to increase under $5 \%$ treatment while showing an opposite trend under the addition levels of $10 \%$ and $20 \%$. The optimal extrusion condition was determined as $140{ }^{\circ} \mathrm{C}$ barrel and die temperature, $200 \mathrm{rpm}$ screw speed and $20 \%$ feed moisture content (wet basis). Similarly, O'Shea et al. (2014) applied apple pomace into a corn-flour-based extruded food product [42]. The optimized parameters for this product were reported as $7.7 \%$ pomace, $150^{\circ} \mathrm{C}$ die head temperature and $69 \mathrm{rpm}$ screw speed. Moreover, the addition of pomace was found to reduce the radical expansion ratio, which in turn negatively affected the texture of the snack. However, contradictory results were reported by Masli et al. (2018), who developed cornstarch-based extrudates with 15\% and 30\% apple 
pomace contents [43]. Higher initial and stable expansion indexes were obtained with the incorporation of $15 \%$ pomace while the mechanical energy cost was lower. Furthermore, higher shrinkage was mentioned, which became more marked with the addition level.

Since many of extruded snacks are gluten-free, it is of great significance to evaluate their sensory acceptance. Ačkar et al. (2018) reported the organoleptic test for the corn extruded snacks with added apple pomace [44]. The incorporation of apple pomace to extruded snacks significantly decreased most of the sensory properties including external appearance, chewiness and flavor. These changes became more obvious with the pomace level increasing from $5 \%$ to $15 \%$. The same decline was exhibited in overall quality but within the acceptable range. Moreover, extruded products of rice and wheat semolina flour with 10\%, 20\% and 30\% apple pomace incorporation were prepared by Reis et al. (2014), with a particular emphasis on the nutritional aspects [34]. As the pomace level reached $30 \%$, the nitrogen solubility index reduced by $23 \%$, which indicated a low protein denaturation. The increases in TPC, TFC and PAC were observed to be 2.8-, 4- and 1.8-fold, respectively. On the contrary, Lohani and Muthukumarappan (2017) reported that $\mathrm{CO}_{2}$ extruded food products based on sorghum flour and apple pomace had decreased hardness and increased crispness [45]. These findings via the application of $\mathrm{CO}_{2}$ extruded food indicate a promising research focus in these areas.

\subsection{Meat Products}

Most of current studies emphasize the application of apple pomace in meat products in order to improve the deficiency in the dietary fiber of meat. Efforts have been made in mutton products, including mutton nuggets [46] and mutton goshtaba (a traditional Kashmiri meatball) [47], as well as chicken products, such as chicken sausages [48] and chicken nuggets [49]. In addition, Younis and Ahmad (2018) prepared buffalo meat patties in which the meat level was substituted by $2 \%$ to $8 \%$ of apple pomace [50]. The contents of fat, moisture and crude fiber were observed to have a significantly positive correlation with the replacement level. Similar trends were detected in cooking yield and thickness of the patties, as well as the texture properties such as firmness and toughness. A decline in cohesiveness and springiness was found as the substitution level exceeded $6 \%$. Younis and Ahmad (2015) used the same level of pomace substitution for buffalo sausages and obtained similar results [51]. However, decreased hardness was reported in fortified chicken products by Jung et al. (2015), who applied $10 \%$ and $20 \%$ of apple pomace as a meat replacement in chicken patties [29]. According to Verma et al. (2010), a similar decline in hardness was exhibited in low-fat chicken nuggets with $8 \%$ to $12 \%(\mathrm{w} / \mathrm{w})$ of pomace [49]. All these tested meat products showed darker and redder color changes and an improved amount of TDF in the final product. When considering different meat types, there was relatively less research on the application of apple pomace in pork products, so this can be regarded as the orientation of future research.

\subsection{Confectionery Products}

Apple pomace is considered as a suitable ingredient to include in the preparation of confectionery due to its high content of pectin and flavor compounds [5]. A jelly product using a puree of apple pomace and quince fruit was developed by Royer et al. (2006) [52]. Another study by Hussein et al. (2015) reported an apple-pomace-based jam made by fruit by-products such as apple pomace, carrot peels, banana peels and mandarin peels [53]. The mixture of each by-product and sugars was stirred and adjusted to $\mathrm{pH} 3.2$ using citric acid until the total soluble solids reached $67^{\circ}$ Brix. It was found that the phosphorus content, TPC and TFC of apple pomace jam were relatively high, with the concentrations of $220 \mathrm{mg} / 100 \mathrm{~g}, 82.5 \mathrm{mg} / 100 \mathrm{~g}$ and $30.1 \mathrm{mg}$ CAT/100 g, respectively. Among all the jams, apple pomace jam gained the highest score in overall acceptability owing to the fruity flavor and satisfying appearance.

\subsection{Dairy Products}

Wang et al. (2019) conducted a study using apple pomace as a natural stabilizer and texturizer in set-type yoghurt [19]. Various concentrations of apple pomace $(0.1 \%, 0.5 \%$ and $1 \% \mathrm{w} / \mathrm{w})$ were combined 
with skim milk and fermented by a mixture of Streptococcus thermophilus and Lactobacillus delbrueckii subsp. bulgaricus at $42{ }^{\circ} \mathrm{C}$. Results showed that the addition of $1 \%$ pomace led to a dramatically higher onset $\mathrm{pH}$ and shorter time of gelation. Moreover, all fortified yoghurts exhibited improved consistency and cohesiveness during 28 days of storage. The potential of freeze-dried apple pomace powder as a dairy ingredient has recently been evaluated by Wang (2018). This study reported that addition of $1 \%$ apple pomace powder increased the gelation $\mathrm{pH}$ and shortened the fermentation time in yogurt manufacturing, eventually developing a more viscoelastic, consistent, and firmer yogurt gel [54]. The same study revealed that adding apple pomace into stirred yogurt allowed even a higher level of pomace to be incorporated (3\%) and resulted in a significant decrease of syneresis along with increase in viscosity, firmness, and cohesiveness of the matrix during 28 days of cold storage. Wang (2018) highlighted the potential of apple pomace as a natural stabilizer, texturizer and source of dietary fiber and polyphenols in dairy products such as yogurt [54]. Owing to the lack of research on the direct application of apple pomace in dairy products, subsequent studies are needed to explore the feasibility and acceptability of such products.

\section{Apple Pomace as a Substrate for Food and Beverage Manufacturing}

\subsection{Using Apple Pomace in Alcoholic Beverages Production}

The fermentation of apple pomace to produce ethanol has been developed for decades due to its minimum land requirement and low cost $[55,56]$. The common method of ethanol production is reported as solid-state fermentation on apple pomace alone $[57,58]$ or on a mixture substrate of pomace and molasses [59]. Simultaneous saccharification and fermentation (SSF) have also been mentioned in recent research [60]. In the food industry, apple pomace is applied to develop mild alcoholic beverages, which is expected to improve their flavor [61].

Madrera et al. (2013) prepared spirits from dry apple pomace and yeast strains including Saccharomyces cereuisiae, Hanseniaspora uvarum and wine dry yeast with B-glucosidase enzyme [62]. Fermentations were carried out under $16 \pm 2{ }^{\circ} \mathrm{C}$ for 4 weeks. The spirits were distilled twice, with an alcohol strength of $20 \%-22 \%(\mathrm{v} / \mathrm{v})$ in the first stage and $60 \%(\mathrm{v} / \mathrm{v})$ in the second stage. All of the spirits showed high alcohol contents, from $261 \mathrm{~g} / \mathrm{hL}$ AA for H. uvarum to $509 \mathrm{~g} / \mathrm{hL}$ AA for S. cereuisiae. However, the enzymatic treatment was considered to be not advisable because of its excessive methanol concentration. Another noteworthy finding was that spirits under different yeast species had significant differences in aromatic composition, which was of great commercial value. Li et al. (2015) prepared apple homogenate cider with koji and S. cereuisiae, individually and in combination [61]. The final products were achieved after 6-day fermentation and 7-day ageing. The greatest fermentation capacity happened in S. cereuisiae monoculture group, with the ethanol production of $7.50 \%(\mathrm{v} / \mathrm{v})$. Cider with koji generated the highest amounts of total sugar, reducing sugar and ester compounds, which were $24.12 \mathrm{~g} / 100 \mathrm{~g}, 22.93$ $\mathrm{g} / 100 \mathrm{~g}$ and $37.35 \%$, respectively. Furthermore, volatile compounds such as 2-methyl-1-butanol and alpha-farnesene that are mainly generated by apple pomace were higher in koji monocultures. This result indicated that apple pomace can be considered as a fruity flavoring in cider products.

\subsection{Apple Pomace as a Substrate for Edible Mushroom Production}

Apple pomace is considered as good support for mushroom cultivation. This is mainly because it is rich in carbohydrate polymers, such as lignin, as well as minerals including nitrogen, both of which are essential nutrients for mushroom growth. Worrall and Yang (1992) cultivated shiitake (Lentinula edodes) and oyster mushrooms (Pleurotus ostreatus and P. sajor-caju) on apple pomace and sawdust, separately and in combination [63]. Higher yield was observed using pomace alone than on sawdust. The combined substrate with $50 \%(\mathrm{w} / \mathrm{w})$ pomace produced five shiitake isolates and two Pleurotus spp. with greater fresh weights than either substrate alone. Park et al. (2012) applied 2.5\%, $5 \%$ and $10 \%$ apple pomace to sawdust and then cultivated P. ostreatus [64]. Their results showed that adding $2.5 \%$ pomace increased the mycelial growth rates in solid culture, liquid culture and solid-state 
fermentation by $34.5 \%, 20 \%$ and $26 \%$, respectively. However, adding more than $5 \%$ pomace was found to negatively affect the mycelia growth. Moreover, Park et al. (2014) determined the optimum conditions for P. ostreatus to produce laccase as $2.5 \%$ apple pomace addition and 9 days of cultivation time [65]. At present, cultivation of mushrooms using apple pomace as a substrate is only in the experimental stage and needs to be commercialized in the future in order to expand its application.

\subsection{Miscellaneous Use and other Potential Application of Apple Pomace}

Madrera et al. (2015) analyzed volatile compounds generated during the fermentation of apple pomace with $S$. cerevisiae, $H$. valbyensis, $H$. uvarum and a combination of $S$. cerevisiae and an inoculated enzyme [66]. A total of 132 volatile compounds belonging to different chemical families were identified, which were found to be strain dependent. Results indicated that fermented apple pomace can be used as a natural flavoring in beverages by maceration or infusion. Huc-Mathis et al. (2019) investigated the emulsifying properties of apple pomace and oat bran [67]. Rapeseed, jojoba and myritol oils were used to obtain 50/50 (w/w) oil in water emulsion. Results indicated that apple pomace can better stabilize emulsions of rapeseed and myritol oil. Therefore, apple pomace can be regarded as a potential stabilizing agent, and its interactions with other common ingredients in food products need further investigations. Bartkiene et al. (2017) applied apple pomace to immobilize Pediococcus acidilactici LUHS29 and added them to wheat-barley sourdough fermentation [68]. An increase of $15.3 \%$ in the lactic acid production was noted during the fermentation of sourdough with immobilized strain. The same trends were found in the TPC and radical scavenging activity, with the increases of $34.6 \%$ and $79.7 \%$, respectively. In this case, owing to its bioactivity, the immobilization of apple pomace matrix bacterial cells can be utilized in the processing of other fermented products.

\section{Major Functional Ingredients and Bioactives that can be Extracted from Apple Pomace}

Major functional bioactive compounds from apple pomace and their bioactivities are listed in Table 3. These functional apple pomace ingredients, including pectin, phenol and fiber can be extracted and applied as functional ingredients in various food products. Due to the high concentration of nutrients, these extracts can play a more obvious role in foods such as cookies [69], ciders [70] and meat products [71]. However, studies related to the extractions of such functional ingredients concentrate mainly on the extraction technologies, and there are relatively few studies on the applications of these extracts in food products.

Table 3. Major bioactive compounds from apple pomace.

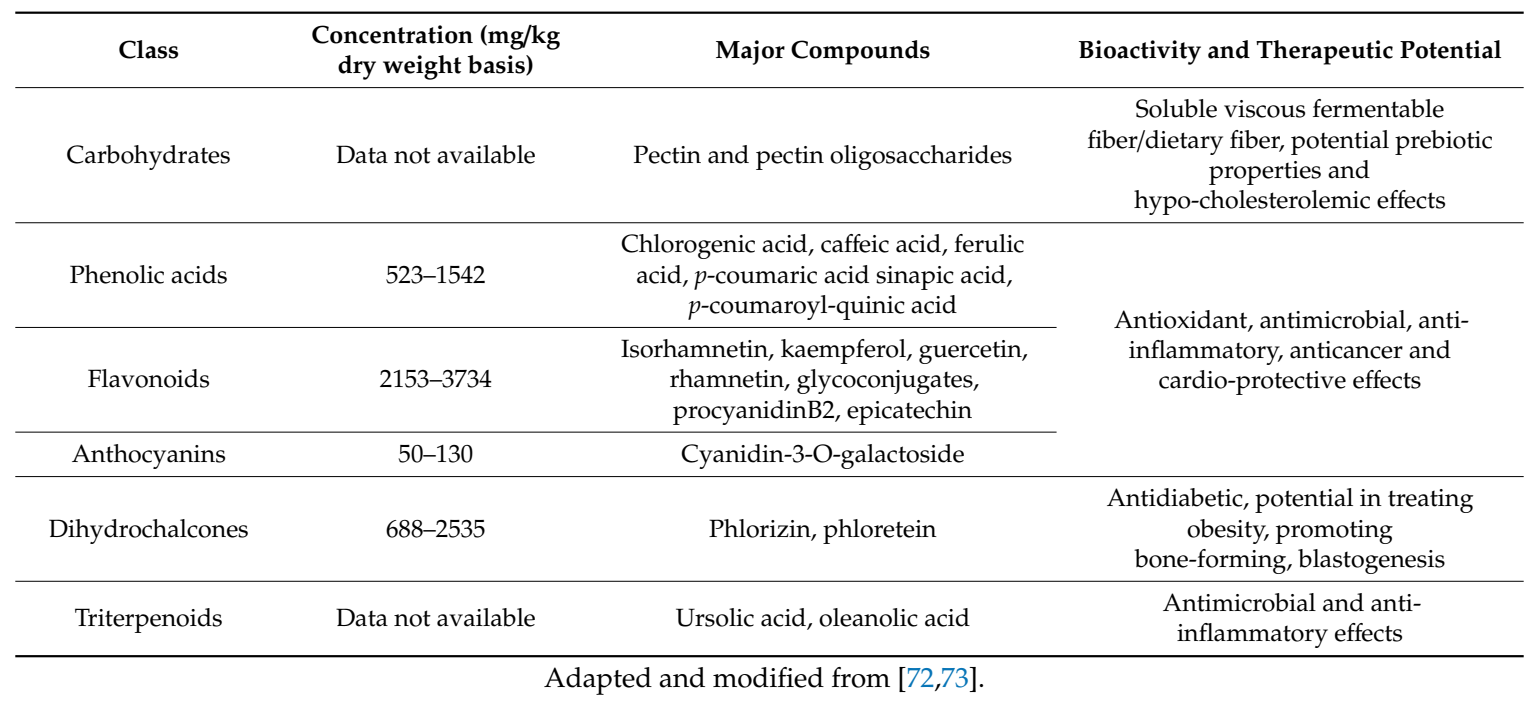




\subsection{Pectin}

Pectin is a soluble viscous fermentable fiber and common additive in the food industry which functions as a gelling agent, emulsifier and thickener in various food products such as confectionery, bakery jellies, yoghurts and beverages [4]. Apple pomace is one of the main fruit sources of pectin, thus, extracting pectin has been regarded as a reasonable approach of pomace utilization [74,75]. Currently, the common extraction methods include enzymatic [76,77], mechanical [78] and chemical extractions [79]. Notably, novel methods are constantly being proposed. For example, Wang et al. (2014) extracted apple pomace pectin by adding $30 \times$ subcritical water. The mixture was heated under $130{ }^{\circ} \mathrm{C}, 150{ }^{\circ} \mathrm{C}$, and $170{ }^{\circ} \mathrm{C}$ for $5 \mathrm{~min}$, the supernatant liquid was filtered, and pectin product was collected by alcohol precipitation, washing and drying. The highest pectin recovery rate $(16.68 \%)$ was found in the treatment of $150{ }^{\circ} \mathrm{C}$ [80]. Additionally, combined extraction techniques using ultrasonic homogenizing and viscozyme (fungal $\beta$-glucanase) treatments were reported by Min et al. (2010) to extract pectin, which was applied in cookie formulations to partially replace shortening [69]. Results showed that with the incorporation of extracted pectin, the height of cookies increased while the diameter decreased. The moisture content increased from $6.72 \%$ to $11.00 \%$ as the replacement level increased from $0 \%$ to $30 \%(\mathrm{w} / \mathrm{w})$, which led to dramatic declines in fracturability and hardness of $21.6 \%$ and $40.2 \%$, respectively. A lighter color was also observed after the addition of replacement. Therefore, apple pomace pectin extract can be used not only to modify the textural properties of the food product but also as a functional ingredient to replace fat in bakery products. However, sensory evaluations to test the acceptability of pectin-fortified food product are required.

\subsection{Phenol}

Phenol extracts from apple pomace mainly consist of phloridzin, epicatechin, chlorogenic acid and quercetin glycosides $[81,82]$. The application of these polyphenols is supposed to affect the organoleptic properties, such as color, flavor and odor, as well as the antioxidant ability of food products $[8,83]$. Therefore, phenol concentrations can be used as both functional ingredients and natural antioxidants. Current phenol extraction methods include maceration and Soxhlet extraction [84,85], enzymatic method [86], ultrasound extraction [87] and microwave extraction [88]. Benvenutti et al. (2019) conducted solid-liquid extraction to prepare phenol concentration and applied 77 and $130 \mathrm{mg} / \mathrm{L}$ of it into cider production [70]. Results showed that the antioxidant activity of ciders increased by 1.6- and 2.8-fold, respectively. A darker and yellower color, as well as accentuated bitterness and astringency, were detected after phenol addition. All of these changes were within the acceptable range. Notably, quercetin glycosides, which only exists in fruit epicarp, were detected in ciders with added pomace phenol extract. There has been relatively little research on the direct use of apple pomace phenol extract, and given its health benefits, further research is needed to develop a variety of phenol-enriched foods.

\subsection{Fiber}

Although apple pomace can be directly used as a functional ingredient in food products, the pomace fiber extract is expected to play a more effective role in fiber enrichment. Fiber extract is applied to provide dietary fiber including pectin, cellulose and lignin in various foods and pharmaceutical products. Issar et al. (2017) developed an acidophilus yoghurt containing apple pomace fiber with the starter culture of Lactobacillus acidophilus and Bifidobacterium longum [89]. The fiber extract was prepared by acid-alkali digestion method and $2.5 \%$ to $10 \%$ of it was added as a functional ingredient. Increasing the amounts of added fiber extract from $0 \%$ to $10 \%$ caused decline in acidity and fat content, with the percentages changed from $0.15 \%$ to $0.09 \%$ and $1.65 \%$ to $1.59 \%$, respectively. Yoghurts with $5 \%$ fiber concentration were considered ideal in the sensory test, gaining the highest scores in color, flavor and consistency. However, the products were regarded as unacceptable when the fiber level exceeded $5 \%$.

In addition, pomace fiber extract can be used as a fat replacer in meat products, which is reported to improve their rheological properties as well as emulsion stability [90]. Choi et al. (2016) made 
uncured, reduced-fat chicken sausages with partially replacing $5 \%$ and $10 \%$ of pork fat by $1 \%$ and $2 \%$ of apple pomace fiber concentration [71]. According to the results, both fat content and caloric energy decreased significantly with the increased substitution level. The same tendencies were found in emulsion stability, such as cooking loss and fat separation. Therefore, fiber extract from apple pomace has been successfully applied to food products to control fat consumption.

\section{Health Hazards Related to Apple Pomace Consumption}

At present, the research on the health hazards of apple pomace is still insufficient and needs further investigations. Existing studies indicated two potential risks of apple pomace consumption, which are natural plant toxins and pesticide residue intake [91]. Apple seed amygdalin, which may induce acute cyanide poisoning, has always been the focus of plant toxin research. However, recent studies have reported that the level of amygdalin in apple seeds is generally safe for human consumption [92]. Approximately $800 \mathrm{~g}$ of apple pomace consumption, which is highly unlikely to occur, is required to cause acute cyanide poisoning in humans [91].

Another potential hazard of apple pomace is pesticide residue, in which neonicotinoids gain great attention because they are not considered sufficient to be removed by commonly available methods [93]. Chen et al. (2014) tested neonicotinoid residues in eight apple varieties and reported that the majority of neonicotinoids had negligible contents [93]. Although acetamiprid was detected in two apple varieties, its levels are considered to have a low risk of toxicity [91]. Additionally, in order to improve the quality and yield of apple fruit, fungicides are increasingly used, which raises great concern regarding safety. According to Liu et al. (2016), the detectable fungicides in apple fruits mainly included thiophanate, carbendazim and pyrimethanil [94]. The United States Environmental Protection Agency (EPA) reported that thiophanate and carbendazim had low acute toxicity [95]. Although the assessment of pyrimethanil remains to be completed, a similar fungicide, cyprodinil, has been regarded as low-risk by the EPA. Moreover, the residue of plant growth regulators such as naphthaleneacetic acid [96] and diphenylamine [97] was also mentioned by several studies, and they are regarded as having no risk and low risk of toxicity by the EPA, respectively $[98,99]$. At present, there is no strong evidence showing health hazards related to apple pomace consumption. However, with the update of pesticides and other chemical agents, future studies are required to continuously explore this problem.

\section{Conclusions}

Apple pomace is a fruit by-product generated from apple juice processing. The common disposal methods of apple pomace can cause environmental pollution and even public health hazards. Apple pomace is rich in nutrients such as carbohydrates, phenolic compounds, dietary fiber and minerals. Therefore, apple pomace can be applied directly or after minimal processing as functional ingredients in various types of food products. For example, apple pomace can improve the dietary fiber content and health-promoting properties of bakery products, such as bread, sweet bakery products and brittle bakery food. Apple pomace can also be incorporated with extruded food and meat products to enhance their nutritional value. Additionally, the utilization of apple pomace in confectionery products and dairy food was found to have contributions to the product quality characteristics. Moreover, it can also be used as a part of the substrate for alcoholic beverage development and edible mushroom cultivation. Further potential applications as flavoring and stabilizing agents were also apparent. In addition, many functional bioactive compounds that are extracted from apple pomace, including pectin, phenol and fiber, can also be utilized in food products to improve the product quality and nutritional properties. Although natural plant toxins and pesticide residues in apple pomace are considered to pose potential health hazards, current studies suggest that apple pomace consumption does not possess serious health risks for human health. The variety of food products that can be incorporated with apple pomace is relatively small. Therefore, more applications need to be explored in the future to solve the problem of excess apple pomace disposal in an environmentally friendly manner and to improve the quality and health aspects of a variety of food products by incorporation of this valuable functional ingredient. 
Author Contributions: Conceptualization, C.S.R. and F.L.; writing-original draft preparation, F.L.; writing-review and editing, C.S.R., S.A., A.G.C., S.F.L. and D.R.P.A. All authors have read and agreed to the published version of the manuscript.

Funding: Research Initiatives Fund, Faculty of Veterinary and Agricultural Sciences, The University of Melbourne, Australia.

Conflicts of Interest: The authors declare no conflict of interest. The funders had no role in the design of the study; in the collection, analyses, or interpretation of data; in the writing of the manuscript, or in the decision to publish the results.

\section{References}

1. Musacchi, S.; Serra, S. Apple Fruit Quality: Overview on Pre-Harvest Factors. Sci. Hortic. 2018, 234, 409-430. [CrossRef]

2. Forsline, P.L.; Aldwinckle, H.S.; Dickson, E.E.; Luby, J.J.; Hokanson, S.C. Collection, Maintenance, Characterization, and Utilization of Wild Apples of Central Asia. In Horticultural Reviews; Janick, J., Ed.; John Wiley \& Sons, Inc.: Oxford, UK, 2010.

3. FAOSTAT. Available online: http://www.fao.org/faostat/zh/\#data/QC/visualize (accessed on 18 March 2019).

4. Shashi, B.; Kalpana, K.; Madhu, S.; Bikram, S.; Ahuja, P.S. Processing of Apple Pomace for Bioactive Molecules. Crit. Rev. Biotechnol. 2008, 28, 285-296.

5. Shalini, R.; Gupta, D.K. Utilization of Pomace from Apple Processing Industries: A Review. J. Food Sci. Technol. 2010, 47, 365-371. [CrossRef] [PubMed]

6. Kammerer, D.R.; Kammerer, J.; Valet, R.; Carle, R. Recovery of Polyphenols from the By-Products of Plant Food Processing and Application as Valuable Food Ingredients. Food Res. Int. 2014, 65, 2-12. [CrossRef]

7. Vendruscolo, F.; Albuquerque, P.M.; Streit, F.; Esposito, E.; Ninow, J.L. Apple Pomace: A Versatile Substrate for Biotechnological Applications. Crit. Rev. Biotechnol. 2008, 28, 1-12. [CrossRef] [PubMed]

8. Perussello, C.A.; Zhang, Z.; Marzocchella, A.; Tiwari, B.K. Valorization of Apple Pomace by Extraction of Valuable Compounds. Compr. Rev. Food Sci. Food Saf. 2017, 16, 776-796. [CrossRef]

9. Singha, P.; Muthukumarappan, K. Single Screw Extrusion of Apple Pomace-Enriched Blends: Extrudate Characteristics and Determination of Optimum Processing Conditions. Food Sci. Technol. Int. 2018, 24, 447-462. [CrossRef]

10. Shah, G.H.; Masoodi, F.A. Studies on the Utilization of Wastes from Apple Processing Plants. Indian Food Pack. 1994, 48, 47.

11. Laufenberg, G.; Kunz, B.; Nystroem, M. Transformation of Vegetable Waste into Value Added Products: (A) the Upgrading Concept; (B) Practical Implementations. Bioresour. Technol. 2003, 87, 167-198. [CrossRef]

12. Wang, H.; Wang, J.; Fang, Z.; Wang, X.; Bu, H. Enhanced Bio-Hydrogen Production by Anaerobic Fermentation of Apple Pomace with Enzyme Hydrolysis. Int. J. Hydrog. Energy 2010, 35, 8303-8309. [CrossRef]

13. Endreß, H.U. High Quality Resulting from Product Integrated Environment Protection-PIUS. Fruit Process. 2000, 10, 273-277.

14. Pirmohammadi, R.; Rouzbehan, Y.; Rezayazdi, K.; Zahedifar, M. Chemical Composition, Digestibility and in Situ Degradability of Dried and Ensiled Apple Pomace and Maize Silage. Small Rumin. Res. 2006, 66, 150-155. [CrossRef]

15. Takahashi, J.; Mori, T. Hydrogen Production from Reaction of Apple Pomace with Water over Commercial Steam Reforming Ni Catalysts. J. Jpn. Pet. Inst. 2006, 49, 262-267. [CrossRef]

16. Roberts, J.S.; Gentry, T.S.; Bates, A.W. Utilization of Dried Apple Pomace as a Press Aid to Improve the Quality of Strawberry, Raspberry, and Blueberry Juices. J. Food Sci. 2004, 69, 181-190. [CrossRef]

17. Gómez, M.; Martinez, M.M. Fruit and Vegetable By-Products as Novel Ingredients to Improve the Nutritional Quality of Baked Goods. Crit. Rev. Food Sci. Nutr. 2018, 58, 2119-2135. [CrossRef]

18. Grigelmo-Miguel, N.; Martín-Belloso, O. Comparison of Dietary Fibre from By-Products of Processing Fruits and Greens and from Cereals. LWT-Food Sci. Technol. 1999, 32, 503-508. [CrossRef]

19. Wang, X.; Kristo, E.; LaPointe, G. The Effect of Apple Pomace on the Texture, Rheology and Microstructure of Set Type Yogurt. Food Hydrocoll. 2019, 91, 83-91. [CrossRef]

20. Jin, H.; Kim, H.S.; Kim, S.K.; Shin, M.K.; Kim, J.H.; Lee, J.W. Production of Heteropolysaccharide-7 by Beijerinckia Indica from Agro-Industrial Byproducts. Enzym. Microb. Technol. 2002, 30, 822-827. [CrossRef] 
21. Jannati, N.; Hojjatoleslamy, M.; Hosseini, E.; Mozafari, H.R.; Siavoshi, M. Effect of Apple Pomace Powder on Rheological Properties of Dough and Sangak Bread Texture. Carpathian J. Foof Sci. Technol. 2018, 10, 77-84.

22. Ktenioudaki, A.; O'Shea, N.; Gallagher, E. Rheological Properties of Wheat Dough Supplemented with Functional By-Products of Food Processing: Brewer's Spent Grain and Apple Pomace. J. Food Eng. 2013, 116, 362-368. [CrossRef]

23. Dhillon, G.S.; Kaur, S.; Brar, S.K. Perspective of Apple Processing Wastes as Low-Cost Substrates for Bioproduction of High Value Products: A Review. Renew. Sustain. Energy Rev. 2013, 27, 789-805. [CrossRef]

24. Will, F.; Olk, M.; Hopf, I.; Dietrich, H. Characterization of Polyphenol Extracts from Apple Juice. Dtsch. Lebensm.-Rundsch. 2006, 102, 297-302.

25. Lu, Y.; Foo, L.Y. Antioxidant and Radical Scavenging Activities of Polyphenols from Apple Pomace. Food Chem. 2000, 68, 81-85. [CrossRef]

26. Schieber, A.; Hilt, P.; Conrad, J.; Beifuss, U.; Carle, R. Elution Order of Quercetin Glycosides from Apple Pomace Extracts on a New HPLC Stationary Phase with Hydrophilic Endcapping. J. Sep. Sci. 2002, 25, 361-364. [CrossRef]

27. Masoodi, F.A.; Chauhan, G.S. Use of Apple Pomace as a Source of Dietary Fiber in Wheat Bread. J. Food Process. Preserv. 1998, 22, 255-263. [CrossRef]

28. Wang, H.J.; Thomas, R.L. Direct Use of Apple Pomace in Bakery Products. J. Food Sci. 1989, 54, 618-620. [CrossRef]

29. Jung, J.; Cavender, G.; Zhao, Y. Impingement Drying for Preparing Dried Apple Pomace Flour and Its Fortification in Bakery and Meat Products. J. Food Sci. Technol. 2015, 52, 5568-5578. [CrossRef] [PubMed]

30. Sudha, M.L.; Baskaran, V.; Leelavathi, K. Apple Pomace as a Source of Dietary Fiber and Polyphenols and Its Effect on the Rheological Characteristics and Cake Making. Food Chem. 2007, 104, 686-692. [CrossRef]

31. Sudha, M.L.; Dharmesh, S.M.; Pynam, H.; Bhimangouder, S.V.; Eipson, S.W.; Somasundaram, R.; Nanjarajurs, S.M. Antioxidant and Cyto/DNA Protective Properties of Apple Pomace Enriched Bakery Products. J. Food Sci. Technol. 2016, 53, 1909-1918. [CrossRef]

32. Martins, Z.E.; Pinho, O.; Ferreira, I.M.P.L.V.O. Food Industry By-Products Used as Functional Ingredients of Bakery Products. Trends Food Sci. Technol. 2017, 67, 106-128. [CrossRef]

33. Masoodi, F.A.; Sharma, B.; Chauhan, G.S. Use of Apple Pomace as a Source of Dietary Fiber in Cakes. Plant Foods Hum. Nutr. 2002, No. 57, 121-128. [CrossRef]

34. Reis, S.F.; Rai, D.K.; Abu-Ghannam, N. Apple Pomace as a Potential Ingredient for the Development of New Functional Foods. Int. J. Food Sci. Technol. 2014, 49, 1743-1750. [CrossRef]

35. Lauková, M.; Kohajdová, Z.; Karovičová, J. Effect of Hydrated Apple Powder on Dough Rheology and Cookies Quality. Potravinarstvo 2016, 10. [CrossRef]

36. Kohajdová, Z.; Karovičová, J.; Magala, M.; Kuchtová, V. Effect of Apple Pomace Powder Addition on Farinographic Properties of Wheat Dough and Biscuits Quality. Chem. Pap. 2014, 68, 1059-1065. [CrossRef]

37. De Toledo, N.M.V.; Nunes, L.P.; da Silva, P.P.M.; Spoto, M.H.F.; Canniatti-Brazaca, S.G. Influence of Pineapple, Apple and Melon By-Products on Cookies: Physicochemical and Sensory Aspects. Int. J. Food Sci. Technol. 2017, 52, 1185-1192. [CrossRef]

38. Alongi, M.; Melchior, S.; Anese, M. Reducing the Glycemic Index of Short Dough Biscuits by Using Apple Pomace as a Functional Ingredient. LWT-Food Sci. Technol. 2019, 100, 300-305. [CrossRef]

39. Mir, S.A.; Bosco, S.J.D.; Shah, M.A.; Santhalakshmy, S.; Mir, M.M. Effect of Apple Pomace on Quality Characteristics of Brown Rice Based Cracker. J. Saudi Soc. Agric. Sci. 2017, 16, 25-32. [CrossRef]

40. Stojceska, V.; Ainsworth, P.; Plunkett, A.; İbanoğlu, Ş. The Advantage of Using Extrusion Processing for Increasing Dietary Fibre Level in Gluten-Free Products. Food Chem. 2010, 121, 156-164. [CrossRef]

41. Karkle, E.L.; Alavi, S.; Dogan, H. Cellular Architecture and Its Relationship with Mechanical Properties in Expanded Extrudates Containing Apple Pomace. Food Res. Int. 2012, 46, 10-21. [CrossRef]

42. O'Shea, N.; Arendt, E.; Gallagher, E. Enhancing an Extruded Puffed Snack by Optimising Die Head Temperature, Screw Speed and Apple Pomace Inclusion. Food Bioprocess Technol. 2014, 7, 1767-1782. [CrossRef]

43. Masli, M.D.P.; Gu, B.J.; Rasco, B.A.; Ganjyal, G.M. Fiber-Rich Food Processing Byproducts Enhance the Expansion of Cornstarch Extrudates. J. Food Sci. 2018, 83, 2500-2510. [CrossRef] [PubMed] 
44. Ačkar, Đ.; Jozinović, A.; Babić, J.; Miličević, B.; Panak Balentić, J.; Šubarić, D. Resolving the Problem of Poor Expansion in Corn Extrudates Enriched with Food Industry By-Products. Innov. Food Sci. Emerg. Technol. 2018, 47, 517-524. [CrossRef]

45. Lohani, U.C.; Muthukumarappan, K. Process Optimization for Antioxidant Enriched Sorghum Flour and Apple Pomace Based Extrudates Using Liquid CO 2 Assisted Extrusion. LWT-Food Sci. Technol. 2017, 86, 544-554. [CrossRef]

46. Huda, A.B.; Parveen, S.; Rather, S.A.; Akthter, R.; Hassan, M. Effect of Incorporation of Apple Pomace on the Physico-Chemical, Sensory and Textural Properties of Mutton Nuggets. Int. J. Adv. Res. 2014, 2, 11.

47. Rather, S.A.; Akhter, R.; Masoodi, F.A.; Gani, A.; Wani, S.M. Utilization of Apple Pomace Powder as a Fat Replacer in Goshtaba: A Traditional Meat Product of Jammu and Kashmir, India. J. Food Meas. Charact. 2015, 9, 389-399. [CrossRef]

48. Yadav, S.; Malik, A.; Sharma, D.; Islam, R.U.; Pathera, A. Development of Dietary Fibre Enriched Chicken Sausages by Incorporating Corn Bran, Dried Apple Pomace and Dried Tomato Pomace. Nutr. Food Sci. 2016, 46, 16-29. [CrossRef]

49. Verma, A.K.; Sharma, B.D.; Banerjee, R. Effect of Sodium Chloride Replacement and Apple Pulp Inclusion on the Physico-Chemical, Textural and Sensory Properties of Low Fat Chicken Nuggets. LWT Food Sci. Technol. 2010, 43, 715-719. [CrossRef]

50. Younis, K.; Ahmad, S. Quality Evaluation of Buffalo Meat Patties Incorporated with Apple Pomace Powder. Buffalo Bull. 2018, 37, 389-401.

51. Younis, K.; Ahmad, S. Waste Utilization of Apple Pomace as a Source of Functional Ingredient in Buffalo Meat Sausage. Cogent Food Agric. 2015, 1, 1119397. [CrossRef]

52. Royer, G.; Madieta, E.; Symoneaux, R.; Jourjon, F. Preliminary Study of the Production of Apple Pomace and Quince Jelly. LWT Food Sci. Technol. 2006, 39, 1022-1025. [CrossRef]

53. Hussein, A.M.S.; Kamil, M.M.; Hegazy, N.A.; Mahmoud, K.F.; Ibrahim, M.A. Utilization of Some Fruits and Vegetables By-Products to Produce High Dietary Fiber Jam. Food Sci. Qual. Manag. 2015, 37, $39-45$.

54. Wang, X. Exploring the Potential of Apple Pomace as a Functional Ingredient in Yogurt. Master's Thesis, The University of Guelph, Guelph, ON, Canada, 2018.

55. Hang, Y.D.; Lee, C.Y.; Woodams, E.E.; Cooley, H.J. Production of Alcohol from Apple Pomace. Appl. Environ. Microbiol. 1981, 42, 1128-1129. [CrossRef]

56. Nogueira, A.; Santos, L.D.; Paganini, C.; Wosiacki, G. Evaluation of the Alcoholic Fermentation of Aqueous Extract of the Apple Pomace. Semin. Ciênc. Agrár. 2005, 26, 187-194. [CrossRef]

57. Hang, Y.D.; Lee, C.Y.; Woodams, E.E. A Solid State Fermentation System for Production of Ethanol from Apple Pomace. J. Food Sci. 1982, 47, 1851-1852. [CrossRef]

58. Ngadi, M.O.; Correia, L.R. Kinetics of Solid-State Ethanol Fermentation from Apple Pomace. J. Food Eng. 1992, 17, 97-116. [CrossRef]

59. Kaur, M. Microbial Transformation of Apple Pomace to Recover Industrial Products. Masters' Thesis, Punjab University, Lahore, Pakistan, 1989.

60. Magyar, M.; da Costa Sousa, L.; Jin, M.; Sarks, C.; Balan, B. Conversion of Apple Pomace Waste to Ethanol at Industrial Relevant Conditions. Appl. Microbiol. Biotechnol. 2016, 100, 7349-7358. [CrossRef]

61. Li, S.; Nie, Y.; Ding, Y.; Zhao, J.; Tang, X. Effects of Pure and Mixed Koji Cultures with Saccharomyces Cerevisiae on Apple Homogenate Cider Fermentation. J. Food Process. Preserv. 2015, 39, 2421-2430. [CrossRef]

62. Madrera, R.R.; Bedriñana, R.P.; Hevia, A.G.; Arce, M.B.; Valles, B.S. Production of Spirits from Dry Apple Pomace and Selected Yeasts. Food Bioprod. Process. Trans. Inst. Chem. Eng. Part C 2013, 91, 623-631. [CrossRef]

63. Worrall, J.J.; Yang, C.S. Shiitake and Oyster Mushroom Production on Apple Pomace and Sawdust. HortScience 1992, 27, 1131-1133. [CrossRef]

64. Park, Y.J.; Park, H.R.; Kim, S.R.; Yoon, D.E.; Son, E.S.; Kwon, O.C.; Han, W.; Lee, C.S. Apple Pomace Increases Mycelial Growth of Pleurotus Ostreatus. Afr. J. Microbiol. Res. 2012, 6, 1075-1078.

65. Park, Y.J.; Yoon, D.E.; Kim, H.ll; Kwon, O.C.; Yoo, Y.B.; Kong, W.S.; Lee, C.S. Overproduction of Laccase by the White-Rot Fungus Pleurotus Ostreatus Using Apple Pomace as Inducer. Mycobiology 2014, 42, $193-197$. [CrossRef] [PubMed] 
66. Madrera, R.R.; Bedriñana, R.P.; Valles, B.S. Production and Characterization of Aroma Compounds from Apple Pomace by Solid-State Fermentation with Selected Yeasts. LWT Food Sci. Technol. 2015, 64, 1342-1353. [CrossRef]

67. Huc-Mathis, D.; Journet, C.; Fayolle, N.; Bosc, V. Emulsifying Properties of Food By-Products: Valorizing Apple Pomace and Oat Bran. Colloids Surf. Physicochem. Eng. Asp. 2019, 568, 84-91. [CrossRef]

68. Bartkiene, E.; Vizbickiene, D.; Bartkevics, V.; Pugajeva, I.; Krungleviciute, V.; Zadeike, D.; Zavistanaviciute, P.; Juodeikiene, G. Application of Pediococcus Acidilactici LUHS29 Immobilized in Apple Pomace Matrix for High Value Wheat-Barley Sourdough Bread. LWT Food Sci. Technol. 2017, 83, 157-164. [CrossRef]

69. Min, B.; Bae, I.Y.; Lee, H.G.; Yoo, S.H.; Lee, S. Utilization of Pectin-Enriched Materials from Apple Pomace as a Fat Replacer in a Model Food System. Bioresour. Technol. 2010, 101, 5414-5418. [CrossRef] [PubMed]

70. Benvenutti, L.; Bortolini, D.G.; Nogueira, A.; Zielinski, A.A.F.; Alberti, A. Effect of Addition of Phenolic Compounds Recovered from Apple Pomace on Cider Quality. LWT Food Sci. Technol. 2019, 100, 348-354. [CrossRef]

71. Choi, Y.S.; Kim, Y.B.; Hwang, K.E.; Song, D.H.; Ham, Y.K.; Kim, H.W.; Sung, J.M.; Kim, C.J. Effect of Apple Pomace Fiber and Pork Fat Levels on Quality Characteristics of Uncured, Reduced-Fat Chicken Sausages. Poult. Sci. 2016, 95, 1465-1471. [CrossRef]

72. Barreira, J.C.; Arraibi, A.A.; Ferreira, I.C. Bioactive and Functional Compounds in Apple Pomace from Juice and Cider Manufacturing: Potential Use in Dermal Formulations. Trends Food Sci. Technol. 2019, 90, 76-87. [CrossRef]

73. Othman, S.B.; Jõudu, I.; Bhat, R. Bioactives From Agri-Food Wastes: Present Insights and Future Challenges. Molecules 2020, 25, 510. [CrossRef]

74. Schieber, A.; Stintzing, F.C.; Carle, R. By-Products of Plant Food Processing as a Source of Functional Compounds-Recent Developments. Trends Food Sci. Technol. 2001, 12, 401-413. [CrossRef]

75. Willats, W.G.; Knox, J.P.; Mikkelsen, J.D. Pectin: New Insights into an Old Polymer Are Starting to Gel. Trends Food Sci. Technol. 2006, 17, 97-104. [CrossRef]

76. Wikiera, A.; Mika, M.; Starzyńska-Janiszewska, A.; Stodolak, B. Development of Complete Hydrolysis of Pectins from Apple Pomace. Food Chem. 2015, 172, 675-680. [CrossRef] [PubMed]

77. Wikiera, A.; Mika, M.; Starzyńska-Janiszewska, A.; Stodolak, B. Endo-Xylanase and Endo-Cellulase-Assisted Extraction of Pectin from Apple Pomace. Carbohydr. Polym. 2016, 142, 199-205. [CrossRef] [PubMed]

78. Adetunji, L.R.; Adekunle, A.; Orsat, V.; Raghavan, V. Advances in the Pectin Production Process Using Novel Extraction Techniques: A Review. Food Hydrocoll. 2017, 62, 239-250. [CrossRef]

79. Orzua, M.C.; Mussatto, S.I.; Contreras-Esquivel, J.C.; Rodriguez, R.; de la Garza, H.; Teixeira, J.A.; Aguilar, C.N. Exploitation of Agro Industrial Wastes as Immobilization Carrier for Solid-State Fermentation. Ind. Crops Prod. 2009, 30, 24-27. [CrossRef]

80. Wang, X.; Chen, Q.; Lü, X. Pectin Extracted from Apple Pomace and Citrus Peel by Subcritical Water. Food Hydrocoll. 2014, 38, 129-137. [CrossRef]

81. Lohani, U.C.; Muthukumarappan, K. Application of the Pulsed Electric Field to Release Bound Phenolics in Sorghum Flour and Apple Pomace. Innov. Food Sci. Emerg. Technol. 2016, 35, 29-35. [CrossRef]

82. Schieber, A.; Hilt, P.; Streker, P.; Endreß, H.U.; Rentschler, C.; Carle, R. A New Process for the Combined Recovery of Pectin and Phenolic Compounds from Apple Pomace. Innov. Food Sci. Emerg. Technol. 2003, 4, 99-107. [CrossRef]

83. Rana, S.; Gupta, S.; Rana, A.; Bhushan, S. Functional Properties, Phenolic Constituents and Antioxidant Potential of Industrial Apple Pomace for Utilization as Active Food Ingredient. Food Sci. Hum. Wellness 2015, 4, 180-187. [CrossRef]

84. Alberti, A.; Zielinski, A.A.F.; Zardo, D.M.; Demiate, I.M.; Nogueira, A.; Mafra, L.I. Optimisation of the Extraction of Phenolic Compounds from Apples Using Response Surface Methodology. Food Chem. 2014, 149, 151-158. [CrossRef]

85. Wijngaard, H.H.; Brunton, N. The Optimisation of Solid-Liquid Extraction of Antioxidants from Apple Pomace by Response Surface Methodology. J. Food Eng. 2010, 96, 134-140. [CrossRef]

86. Oszmiański, J.; Wojdyło, A.; Kolniak, J. Effect of Pectinase Treatment on Extraction of Antioxidant Phenols from Pomace, for the Production of Puree-Enriched Cloudy Apple Juices. Food Chem. 2011, 127, 623-631. [CrossRef] [PubMed] 
87. Ajila, C.M.; Brar, S.K.; Verma, M.; Tyagi, R.D.; Valéro, J.R. Solid-State Fermentation of Apple Pomace Using Phanerocheate Chrysosporium-Liberation and Extraction of Phenolic Antioxidants. Food Chem. 2011, 126, 1071-1080. [CrossRef]

88. Bai, X.; Yue, T.; Yuan, Y.; Zhang, H. Optimization of Microwave-Assisted Extraction of Polyphenols from Apple Pomace Using Response Surface Methodology and HPLC Analysis. J. Sep. Sci. 2010, 33, 3751-3758. [CrossRef]

89. Issar, K.; Sharma, P.C.; Gupta, A. Utilization of Apple Pomace in the Preparation of Fiber-Enriched Acidophilus Yoghurt. J. Food Process. Preserv. 2017, 41, e13098. [CrossRef]

90. Choi, Y.S.; Choi, J.H.; Han, D.J.; Kim, H.Y.; Lee, M.A.; Kim, H.W.; Jeong, J.Y.; Kim, C.J. Characteristics of Low-Fat Meat Emulsion Systems with Pork Fat Replaced by Vegetable Oils and Rice Bran Fiber. Meat Sci. 2009, 82, 266-271. [CrossRef]

91. Skinner, R.C.; Gigliotti, J.C.; Ku, K.-M.; Tou, J.C. A Comprehensive Analysis of the Composition, Health Benefits, and Safety of Apple Pomace. Nutr. Rev. 2018, 76, 893-909. [CrossRef]

92. Opyd, P.M.; Jurgoński, A.; Juśkiewicz, J.; Milala, J.; Zduńczyk, Z.; Król, B. Nutritional and Health-Related Effects of a Diet Containing Apple Seed Meal in Rats: The Case of Amygdalin. Nutrients 2017, 9, 1091. [CrossRef]

93. Chen, M.; Tao, L.; McLean, J.; Lu, C. Quantitative Analysis of Neonicotinoid Insecticide Residues in Foods: Implication for Dietary Exposures. J. Agric. Food Chem. 2014, 62, 6082-6090. [CrossRef]

94. Liu, S.; Che, Z.; Chen, G. Multiple-Fungicide Resistance to Carbendazim, Diethofencarb, Procymidone, and Pyrimethanil in Field Isolates of Botrytis Cinerea from Tomato in Henan Province, China. Crop Prot. 2016, 84, 56-61. [CrossRef]

95. Environmental Protection Agency. US EPA-Pesticides-Fact Sheet for Thiophanate-methyl. Available online: https://www3.epa.gov/pesticides/chem_search/reg_actions/reregistration/fs_PC-102001_1-Nov-04. pdf (accessed on 29 February 2020).

96. Maiti, B.; Desai, S.R.; Krishnamoorthy, T.S. Determination of Naphthaleneacetic Acid Residue in Apples by High-Performance Liquid Chromatography. Analyst 1988, 113, 667-668. [CrossRef] [PubMed]

97. Lozowicka, B. Health Risk for Children and Adults Consuming Apples with Pesticide Residue. Sci. Total Environ. 2015, 502, 184-198. [CrossRef] [PubMed]

98. Environmental Protection Agency. Reregistration Eligibility Decision (RED): Naphthaleneacetic Acid, Its Salts, Ester, and Acetamide. Available online: https://www3.epa.gov/pesticides/chem_search/reg_actions/ reregistration/red_G-91_26-May-04.pdf (accessed on 29 February 2020).

99. Environmental Protection Agency. US EPA-Pesticides-Fact Sheet for Diphenylamine. Available online: https://www3.epa.gov/pesticides/chem_search/reg_actions/reregistration/fs_PC-038501_10-Apr-98. pdf (accessed on 29 February 2020). 